\title{
Críticas de Rawls a Hobbes e críticas de Habermas a Rawls
}

\author{
Raws as a critic of Hobbes, and Habermas' criticisms to Rawls
}

\section{Delamar José Volpato Dutra*}

Universidade Federal de Santa Catarina, Florianópolis, SC, Brasil

\section{Resumo}

O texto apresenta o que considera ser a principal crítica de Rawls a Hobbes, qual seja, de adolescer de um déficit obrigacional decorrente de sua argumentação baseada em uma teoria da decisão racional. Incontinente, apresenta o que considera ser a principal crítica de Habermas a Rawls, qual seja, aquela de um déficit cognitivo decorrente da estratégia argumentativa baseada na posição original. Defende-se que Habermas imputa a Rawls a crítica que este fizera a Hobbes, implicando um déficit deontológico de sua teoria, déficit este que seria inconsistente com a defesa da inviolabilidade da pessoa por ele defendida.

Palavras-chave: Habermas. Rawls. Hobbes. Teoria da justiça. Contratualismo.

\section{Abstract}

The text presents what considers to be the main criticism of Rawls to Hobbes, which is an obligational deficit due to Rawls's argumentation based on a theory of rational decision.

* DVD: Doutor, e-mail: djvdutra@yahoo.com.br 
Incontinent, presents what considers to be Habermas's main criticism to Rawls, namely, that of a cognitive deficit arising from the argumentative strategy of the original position. It is argued that Habermas imputes to Rawls the criticism that Rawls himself had made to Hobbes, implying a deontological deficit in Hobbes theory, a deficiency that, if imputed to Rawls, is inconsistent with his strong defense of the inviolability of the person.

Keywords: Habermas. Rawls. Hobbes. Theory of justice. Contractualism.

\section{Introdução ${ }^{1}$}

De acordo com Rawls, "Hobbes's Leviathan is the greatest single work of political thought in the English language" ${ }^{2}$. A grandeza de um autor pode ser medida pelas críticas que lhe são feitas, bem como pelo status dos nomes que o criticam. Dentre as muitas críticas que lhe foram endereçadas, como a de ser um positivista jurídico ${ }^{3}$, duas são de particular relevo. Um primeiro conjunto delas pode ser agregado sob a denominação de déficit obrigacional. Essa crítica se refere ao vínculo que as normas portam em relação à vontade do sujeito que deve cumpri-las. Ela porta conexão com a estabilidade social ${ }^{4}$, a qual também pode ser analisada mediante a relação entre teoria e prática. Pode-se considerar Kant como um dos primeiros críticos de Hobbes nesse sentido em seu texto Contra Hobbes ${ }^{5}$. Alinham-se nesse viés também Nagel ${ }^{6}$, Rawls ${ }^{7}$ e

\footnotetext{
As referências a Kant seguem a uniformização proposta pela Kant-Studien Redaktion, disponíveis em <http://www.kant. uni-mainz.de/ks/abhandlungen.html>, incluso para as abreviaturas das obras que menciona. As citações literais são feitas a partir das traduções para o vernáculo das obras referidas.

2 RAWLS, J. Lectures on the History of Political Philosophy. Cambridge, MA: Harvard University Press, p. 23, 2007.

3 HART, H. L. A. The Concept of Law. 2. ed., Oxford: Clarendon Press, p. 63, 1994 [1961]. HAMPTON, J. Hobbes and the Social Contract Tradition. Cambridge: Cambridge University Press, p. 244, 1986. HECK, J. N. Thomas Hobbes: passado e futuro. Goiânia: EdUFG, p. 135-6, 2004.

4 RAWLS, J. A Theory of Justice. [Revised Edition]. Oxford: Oxford University Press, p. 435, 1999 [1971], §76.

5 KANT, I. Sobre a expressão corrente: isso pode ser correcto na teoria, mas nada vale na prática. [Trad. Artur Morão]. Covilhã: Lusofia Press, s/d [1793]. Disponível em: <http://www.lusosofia.net/>.

6 NAGEL, T. Hobbes's Concept of Obligation. Philosophical Review. p. 68-83, v. 68, 1959.

7 RAWLS, J. Lectures on the History of Political Philosophy. Cambridge: Harvard University Press, 2007.
} 
Habermas. ${ }^{8}$ Nesse sentido, as obras de Taylor ${ }^{9}$ e Warrender ${ }^{10}$ podem ser consideradas como uma tentativa de resposta à essa problemática. Uma segunda crítica se refere ao que se poderia chamar de déficit cognitivo presente no contratualismo de Hobbes. Essa é a principal objeção de Habermas ${ }^{11}$ a Hobbes. Aliás, Habermas ${ }^{12}$ não só imputa essa crítica também a Rawls, como lhe acresce, ainda, aquela que este imputara a Hobbes.

Pretende-se nesse estudo tratar das críticas de Rawls a Hobbes, bem como da crítica de Habermas a Rawls.

\section{0 argumento de Hobbes contra o louco}

Warrender defendeu a tese de que a obrigação em Hobbes se fundamentaria em um mandamento de Deus. A sua tese é a de que a lei natural não teria sentido obrigacional se ela não fosse um comando divino $^{13}$. Taylor vislumbrou nas declarações de Hobbes, especialmente na distinção do De cive entre um homem justo e uma ação justa, algo equivalente ao imperativo categórico ${ }^{14}$. Sabidamente, tais interpretações são problemáticas, pois parecem não honrar o caráter contratual das obrigações em Hobbes: "There being no obligation on any man, which ariseth not from some act of his own"15. Em qualquer contrato, há uma renúncia de

8 HABERMAS, J. Theorie und praxis. Frankffurt am Main: Suhrkamp, 1971 [1968], cap. 1. Este capítulo tinha sido já publicado em 1963.

9 TAYLOR, A. E. The Ethical Doctrine of Hobbes. Philosophy. n. 13, p. 406-424, 1938.

10 WARRENDER, H. The Political Philosophy of Hobbes. Oxford: Oxford University Press, 1957.

11 HABERMAS, J. Faktizität und Geltung: Beiträge zur Diskurstheorie des Rechts und des demokratischen Rechtsstaats. 4. Auflage, Frankfurt am Main: Suhrkamp, 1994 [1992], cap. III.

12 HABERMAS, J. The Inclusion of the Other: Studies in Political Theory. [Transl. Ciaran Cronin: Die Einbeziehung desanderen Studien zur politischen Theorie]. Cambridge: MIT Press, 1998 [1996], cap. 2. Este capítulo foi publicado em 1995: HABERMAS, J. Reconciliation through the Public Use 0 Reason: Remarks on John Rawl's Political Liberalism. The Journal of Philosophy. New York, v. 92, n. 3, p. 109-31, Mar. 1995.

13 WARRENDER, H. The Political Philosophy of Hobbes. Oxford: Oxford University Press, p. 322, 1957.

14 TAYLOR, A. E. The Ethical Doctrine of Hobbes. Philosophy, n. 13, p. 406-424, 1938.

15 HOBBES, T. Leviathan, or Matter, Form, and Power of a Commonwealth Ecclesiastical and Civil. [Edited by C.B. Macpherson]. London: Penguin, 1968 [1651], chap. XXI. 
direitos, a qual cria obrigações, o que significa dizer que os vínculos são estabelecidos na proporção inversa da renúncia a direitos naturais:

And when a man hath in either manner abandoned, or granted away his Right; then is he said to be OBLIGED, or BOUND, not to hinder those, to whom such Right is granted, or abandoned, from the benefit of it: and that he ought, and it is his DUTY, not to make voyd that voluntary act of his own: and that such hindrance is INJUSTICE, and INJURY, as being Sine Jure; the Right being before renounced, or transferred ${ }^{16}$.

Segundo as palavras do comentador, "Hobbes defines 'obligation' as abandoning or granting away a right (for example, in a contract)" 17 .

Quiçá, o ponto mais importante para esclarecer a fundamentação das leis naturais em Hobbes, bem como para esclarecer a fundamentação do caráter obrigacional dos contratos, seja aquele do argumento contra o louco ou contra o tolo [foole]. O argumento contra o tolo consiste em defender, sob o ponto de vista do interesse próprio, a racionalidade do cumprimento da sua parte do contrato, quando o outro já cumpriu a sua. Hobbes alega que não é racional deixar de cumpri-lo, pois o possível benefício resultante do seu descumprimento, por mais garantido que fosse, só ocorreria por acidente, de tal forma que não poderia ser razoavelmente e sabiamente escolhida tal opção:

For the manifestation whereof, we are to consider; First, that when a man doth a thing, which notwithstanding any thing can be foreseen, and reckoned on, tendeth to his own destruction, howsoever some accident which he could not expect, arriving may turne it to his benefit; yet such events do not make it reasonably or wisely done $e^{18}$.

Para Hobbes, o rompimento unilateral do contrato gera um tipo de desconfiança que implica a expulsão do faltoso de qualquer sociedade. Ou seja, para ele continuar a viver em sociedade, o que, aliás, é

${ }^{16}$ HOBBES, T. Leviathan, or Matter, Form, and Power of a Commonwealth Ecclesiastical and Civil. [Edited by C.B. Macpherson]. London: Penguin, 1968 [1651], chap. XIV.

17 DARWALL, S. The British Moralists and the Internal 'Ought': 1640-1740. Cambridge: Cambridge University Press, 1995, p. 54.

${ }_{18}$ HOBBES, T. Leviathan, or Matter, Form, and Power of a Commonwealth Ecclesiastical and Civil. [Edited by C.B. Macpherson]. London: Penguin, 1968 [1651], chap. XV. 
essencial para a sua sobrevivência, ele dependeria de os outros terem um juízo falso a seu respeito, ou seja, como sendo cumpridor dos contratos, o que ele na verdade não seria. Contudo, não é razoável ou sábio fazer a própria segurança depender de um erro de avaliação dos outros ${ }^{19}$.

Segundo Kavka, o argumento contra o louco mostra que o critério de racionalidade em Hobbes não é nem utilitarista e nem é uma análise caso a caso, mas é uma consideração da propriedade da regra de ser um meio de autoconservação ${ }^{20}$. O cerne do argumento, para ele, residiria na noção de incerteza. Nesse sentido, esclarece ele, seriam quatro os elementos que caracterizam a racionalidade baseada na incerteza defendida por Hobbes no argumento contra o louco. Em primeiro lugar, o raciocínio seria sempre prospectivo (forward-looking), ou seja, o adimplemento de um contrato no presente seria sempre avaliado como um "means to securing future cooperation and trust from other people" 21. Em segundo lugar, as escolhas seriam feitas sob condição de incerteza, ou seja, os resultados que possivelmente adviriam das escolhas caso a caso não estariam disponíveis ${ }^{22}$. Em terceiro lugar, o jogo "play it safe under uncertainty" seria diferente de um cálculo de utilidade caso a caso:

it is rational to play it safe under uncertainty and avoid risking very bad outcomes in hopes of obtaining uncertain gains. In particular, it is irrational to risk social ostracism by committing an offensive violation of a core moral rule (i.e., a law of nature) in hope of obtaining the relatively small and uncertain gains that might follow from getting away with such a violation ${ }^{23}$.

19 "He therefore that breaketh his Covenant, and consequently declareth that he thinks he may with reason do so, cannot be received into any Society, that unite themselves for Peace and Defence, but by the errour of them that receive him; nor when he is received, be retayned in it, without seeing the danger of their errour; which errours a man cannot reasonably reckon upon as the means of his security: and therefore if he be left, or cast out of Society, he perisheth; and if he live in Society, it is by the errours of other men, which he could not foresee, nor reckon upon; and consequently against the reason of his preservation; and so, as all men that contribute not to his destruction, forbear him onely out of ignorance of what is good for themselves." [HOBBES, T. Leviathan, or Matter, Form, and Power of a Commonwealth Ecclesiastical and Civil. [Edited by C.B. Macpherson]. London: Penguin, 1968 [1651], chap. XV].

20 KAVKA, G. The Rationality of Rule-Following: Hobbes' Dispute with the Foole. Law and Philosophy, p. 21, v. 14, 1995.

${ }^{21}$ KAVKA, G. The Rationality of Rule-Following: Hobbes' Dispute with the Foole. Law and Philosophy, p. 21, v. 14, 1995.

22 KAVKA, G. The Rationality of Rule-Following: Hobbes' Dispute with the Foole. Law and Philosophy, p. 21, v. 14, 1995.

${ }_{23}$ KAVKA, G. The Rationality of Rule-Following: Hobbes' Dispute with the Foole. Law and Philosophy. v. 14, p. 21-22, 1995. 
Portanto, o louco argumentaria a partir do benefício caso a caso e Hobbes responderia em termos de longo prazo. Em quarto lugar, seguir regras rigidamente, a longo prazo, seria mais seguro para a autoconservação:

precommitment (or rigid rule-following) is rational in the following sense: one is likely to do better overall by rigidly following the core moral rules than by calculating acceptable risks on particular occasions, because errors and biases in such calculations will tend toward leading you to take excessive risks in particular cases $^{24}$.

Em suma, "Since the benefits of violation are uncertain, and the risks of failure are so grave, it is rational, in purely forward-looking terms, to play it safe and follow the generally beneficial third (or other) law of nature"25. Darwall também argumenta nesse mesmo sentido da incerteza ${ }^{26}$.

Desse modo, o jogo play it safe under uncertainty explicaria não só porque é racional cumprir os contratos no estado civil, mas também porque é racional fazer a guerra no estado de natureza, pois tratar-se-iam de perspectivas de sobrevivência a longo prazo, sob circunstâncias diferentes. Ora, no estado de natureza tal perspectiva de sobrevivência é quase zero, mesmo fazendo a guerra, ao passo que no estado civil é uma perspectiva alta ${ }^{27}$. Decorre disso que o cumprimento dos contratos ditado pela terceira lei natural, incluso aí o contrato social, é posto como condição para a autoconservação e para a paz.

O argumento contra o louco mostra a conexão entre a lei natural, a autopreservação e a motivação. Ele mostra por que o louco avalia mal o que lhe é benéfico, talvez, devido à sua visão de curto prazo. Em última análise, o argumento que opera é aquele da quebra da confiança,

24 KAVKA, G. The Rationality of Rule-Following: Hobbes' Dispute with the Foole. Law and Philosophy. v. 14, p. 21-22, 1995.

25 KAVKA, G. The Rationality of Rule-Following: Hobbes' Dispute with the Foole. Law and Philosophy. v. 14, p. 23, 1995.

26 "To put the point in today's decision- theoretic terms, Hobbes's position appears to be that when it comes to keeping or breaking covenant, rational deliberators will treat the problem not as a decision under conditions of risk, where they attempt to estimate and take account of the likelihood of various outcomes, but as one of uncertainty, where they cannot rationally take such estimates into account" [DARWALL, S. The British Moralists and the Internal 'Ought': 1640-1740. Cambridge: Cambridge University Press, p. 76,1995].

27 KAVKA, Gregor. The Rationality of Rule-Following: Hobbes' Dispute with the Foole. Law and Philosophy. V. 14, 1995, p. 23. 
aliás, o mesmo que opera na primeira fórmula do imperativo categórico a respeito da falsa promessa, justamente o único dever cujo descumprimento gera um tipo de autocontradição, ou seja, gera uma impossibilidade interna. Pergunta-se, qual é mesmo o sentido dessa alegada impossibilidade interna que gera uma contradição? Nada mais do que a quebra da confiança, a qual "tornaria impossível o próprio prometer e o fim que se pode ter com isso, porque ninguém acreditaria que algo teria sido prometido a ele, mas rir-se-ia de todo proferimento semelhante como uma vã alegação" ${ }^{28}$, ou seja, geraria uma falta de confiança. Ora, é justamente a quebra da confiança que gera a expulsão do faltoso e o condena ao estado de natureza, um estado miserável de guerra, cuja chance de sobrevivência é praticamente zero.

Frente aos cálculos da razão, o louco não pode simplesmente desejar continuar no estado de natureza, pois isso estaria em contradição com sua própria autopreservação:

The estate of hostility and war being such, as thereby nature itself is destroyed, and men kill one another [...] he therefore that desireth to live in such an estate, as is the estate of liberty and right of all to all, contradicteth himself. For every man by natural necessity desireth his own good, to which this estate is contrary, wherein we suppose contention between men by nature equal, and able to destroy one another ${ }^{29}$.

\section{A crítica de Rawls ao conceito de obrigação em Hobbes}

É de se mencionar, por oportuno, a relação do argumento contra o louco com o conceito de obrigação. É o que, por exemplo, faz Rawls. De fato, após a análise do argumento contra o louco, Rawls conclui que, nele, Hobbes não apela à noção de obrigação moral: “The argument against the fool shows, I think, that Hobbes does not in fact appeal to a notion of moral obligation (as normally understood) in this argument" 30 . Veja-se, no

28 KANT, I. Fundamentação da metafísica dos costumes. [Trad. G. A. de Almeida: Grundlegung zur Metaphysik der Sitten]. São Paulo: Discurso Editorial/Barcarolla, 2009 [1785], p. 422 [GMS, AA 04: 422].

29 HOBBES, T. The Elements of Law Natural and Politic. Cambridge: Cambridge University Press, 1928 [1640], cap. 14, §12.

30 RAWLS, J. Lectures on the History of Political Philosophy. Cambridge, MA: Harvard University Press, p. 70, 2007. 
entanto, que Rawls observa se tratar da obrigação moral "como normalmente é entendida". Ato contínuo, ele explica, então, como ela é normalmente entendida. Segundo um tal entendimento, para que haja uma obrigação moral duas condições deveriam ser cumpridas.

De acordo com a primeira condição, uma obrigação, como normalmente é entendida, ou ao menos como Rawls pensa que ela seja normalmente entendida, deveria valer mesmo que o seu cumprimento envolvesse uma perda total para o que a cumpre, ou seja, ainda que ele não tivesse nenhuma vantagem, mesmo que a longo prazo: "promises are to be [kept] even at some loss, as things turn out, to one's advantage, even when this is a certain overall loss" 31 . Essa análise da obrigação é, sem dúvida, de estirpe kantiana. Mesmo um autor como Hart a formula em termos semelhantes. De acordo com ele, uma obrigação pode decorrer de um dever moral ou de um ato da pessoa. Seja como for, o importante é que se distinga entre ter uma obrigação e ser obrigado $a^{32}$. De acordo com o primeiro conceito, uma obrigação permanece válida ainda que haja motivos para não a cumprir: "Thus the statement that a person had an obligation, e.g. to tell the truth or report for military service, remains true even if he believed (reasonably or unreasonably) that he would never be found out and had nothing to fear from disobedience" ${ }^{\prime 33}$. É precisamente este o ponto que traduz a ideia de sacrifício presente na definição do conceito de obrigação: "Hence obligations and duties are thought of as characteristically involving sacrifice or renunciation, and the standing possibility of conflict between obligation or duty and interest is, in all societies, among the truisms of both the lawyer and the moralist" 34 .

Uma possibilidade de explicar o que significa essa perda total em Rawls seria tomar a prioridade do justo sobre o bem de forma absoluta. Não se vê outra alternativa para uma tal explicação senão o recurso a Kant, especificamente, ao seu tratamento do jus necessitatis. Com efeito, nesse particular, Kant afirma ser um dever incondicional

\footnotetext{
31 RAWLS, J. Lectures on the History of Political Philosophy. Cambridge, MA: Harvard University Press, p. 70, 2007.

32 HART, H. L. A. The Concept of Law. 2. ed., Oxford: Clarendon Press, 1994 [1961]. p. 82.

33 HART, H. L. A. The Concept of Law. 2. ed., Oxford: Clarendon Press, 1994 [1961]. p. 83.

34 HART, H. L. A. The Concept of Law. 2. ed., Oxford: Clarendon Press, 1994 [1961]. p. 87.
} 
não tirar a vida de outro que não age injustamente, ao passo que é um dever condicional preservar a própria vida ${ }^{35}$. Aqui, entende-se como pode haver uma perda total decorrente de uma obrigação estabelecida categoricamente pela razão. A perda total é a própria vida para dar cumprimento ao dever incondicional de não tirar a vida de outro que não age injustamente. Ora, como o próprio Rawls observa, a lei natural não fundamenta uma obrigação absoluta, já que depende do que os outros farão ${ }^{36}$. Ela não é uma obrigação que se cumpre unilateralmente, como um dever absoluto, pois fazer isso seria se expor como presa aos outros, como estabelece o cap. XIV do Leviathan ${ }^{37}$.

A segunda condição, por seu turno, se refere à equidade e ao equilíbrio de perdas e vantagens entre os contratantes, ou seja, "are considerations of fairness and the distributions of gains and losses among, e.g., the parties to an agreement" 38 . Um contrato ou promessa para ser razoável teria que satisfazer certas condições de equidade: "A reasonable bargain is one which satisfies certain conditions of background fairness" 39 . Sabidamente, "Hobbes says that a promise is binding even when one is coerced into making it" ${ }^{40}$, conforme o Leviathan, cap. XIV.

Rawls sumariza a conclusão que se segue de suas duas teses do seguinte modo:

Thus, I conclude that Hobbes's view, as expressed in his reply to the fool, does not permit room for the ordinary notion of moral obligation (re promises, e.g.) because this notion involves some concern for fairness (e.g. re the circumstances under which promises are given) and for honoring promises even when we

35 KANT, I. Sobre a expressão corrente: isso pode ser correcto na teoria, mas nada vale na prática. [Trad. Artur Morão]. Covilhã: Lusofia Press, s/d [1793]. Disponível em: <http://www.lusosofia.net/>, p. 31-32 [TP, AA 08: 300 nota].

36 RAWLS, John. Lectures on the History of Political Philosophy. Cambridge, MA: Harvard University Press, 2007. p. 66.

37 "But if other men will not lay down their Right, as well as he; then there is no Reason for any one, to devest himselfe of his: For that were to expose himselfe to Prey, (which no man is bound to) rather than to dispose himselfe to Peace. This is that Law of the Gospell; Whatsoever you require that others should do to you, that do ye to them. And that Law of all men, Quod tibi fieri non vis, alteri ne feceris". [HOBBES, T. Leviathan, or Matter, Form, and Power of a Commonwealth Ecclesiastical and Civil. [Edited by C.B. Macpherson]. London: Penguin, 1968 [1651], chap. XIV].

38 RAWLS, J. Lectures on the History of Political Philosophy. Cambridge, MA: Harvard University Press, 2007. p. 70.

39 RAWLS, J. Lectures on the History of Political Philosophy. Cambridge, MA: Harvard University Press, 2007 p. 70.

40 RAWLS, J. Lectures on the History of Political Philosophy. Cambridge, MA: Harvard University Press, 2007 p. 70. 
might do better. And if we take Hobbes's account of practical reason strictly, it seems that both of these are ruled out $t^{41}$.

Essa interpretação de Rawls pode ser melhor compreendida a partir de um estudo de Nagel sobre a matéria. Nagel comunga com a tese de Taylor-Warrender de que a teoria da motivação baseada no autointeresse "is the ruin of any attempt to put a truly moral construction on Hobbes's concept of obligation" 42 , de tal forma que "a genuine feeling of moral obligation can never play a part in their deliberations" 43 . Sabidamente, essa é razão pela qual Warrender e Taylor procuraram por um outro fundamento da obrigação em Hobbes. Seja como for, Nagel não segue esse caminho. O que ele faz é retirar a consequência da tese avançada, qual seja, "genuine moral obligation plays no part in Leviathan at all, but that what Hobbes calls moral obligation is based exclusively on considerations of rational self-interest" 44 .

Sem embargo dessas teses de Nagel e de Rawls, poder-se-iam fazer duas defesas em nome de Hobbes.

A primeira delas é com relação ao primeiro déficit da dedução do razoável a partir do racional, qual seja, um déficit deontológico, haja vista a obrigação, em Hobbes, nunca exigir uma perda total sobre a sensibilidade. De fato, o sistema de Hobbes não comporta uma perda global, se isso envolver o caso extremo. A consideração de casos extremos pode ser usada para testar uma certa teoria, o que o próprio Kant parece fazer no seu texto Sobre a expressão corrente: isso pode ser correto na teoria, mas nada vale na prática, por exemplo, ao se pronunciar sobre o direito no estado de necessidade. No caso de Hobbes, Lloyd afirma que os casos extremos são essenciais: "But for Hobbes's project, the 'extreme' cases are central"45. Quais seriam esses casos extremos que ela considera? Basicamente, os fundamentalismos religiosos, os quais teriam

\footnotetext{
${ }^{41}$ RAWLS, J. Lectures on the History of Political Philosophy. Cambridge, MA: Harvard University Press, 2007. p. 71.

42 NAGEL, T. Hobbes's Concept of Obligation. Philosophical Review, p. 74, v. 68, 1959.

43 NAGEL, T. Hobbes's Concept of Obligation. Philosophical Review, p. 75, v. 68, 1959.

${ }^{44}$ NAGEL, T. Hobbes's Concept of Obligation. Philosophical Review, p. 69, v. 68, 1959.

${ }^{45}$ LLOYD, S. A. Morality in the Philosophy of Thomas Hobbes: Cases in the Law of Nature. Cambridge: Cambridge University Press, 2009. p. 399.
}

Rev. Filos., Aurora, Curitiba, v. 29, n. 47, p. 667-700, maio/ago. 2017 
compromissos transcendentes e não negociáveis: mártires, seguidores do Hamas, Al Qaeda e Jihad ${ }^{46}$. Ainda que ela não analise o estado de necessidade, retém-se para o presente estudo a sua dicção de que a teoria de Hobbes não pode simplesmente ignorar os casos extremos:

But for Hobbes's project, the 'extreme' cases are central. They are ineliminable from his account of disorder, and so cannot be excluded from any model of rational cooperation adequate to address that problem. No model that required their exclusion could be in a relevant sense Hobbesian ${ }^{47}$.

Também a teoria de Kant não ignorou casos extremos, como aquele do estado de necessidade do qual aqui se trata. Aliás, ele tratou do mesmo, tanto na Doutrina do direito, quanto no texto Contra Hobbes.

Nesse ponto, Hobbes pode alegar, em sua defesa, que pelo menos ele mantém a coerência de seu sistema, mesmo no caso extremo. Deveras, o fim que fundamenta a lei natural é o mesmo que a excepciona na circunstância extrema. Nesse diapasão, seria de se perguntar se Rawls estaria disposto a manter o que Kant manteve em relação ao caso extremo ou se ele não tergiversaria com argumentos hobbesianos, por exemplo, na defesa da segurança e da ordem pública. Com efeito, eis o que ele afirma:

the tolerant sects have the right not to tolerate the intolerant in at least one circumstance, namely, when they sincerely and with reason believe that intolerance is necessary for their own security. [...] Since it can never be to men's advantage, from a general point of view, to forgo the right of self-protection ${ }^{48}$.

46 LLOYD, S. A. Morality in the Philosophy of Thomas Hobbes: Cases in the Law of Nature. Cambridge: Cambridge University Press, 2009. p. 397. Ela acusa a proposta do contratualismo moral de Gauthier de ter desconsiderado tais casos extremos [LLOYD, S. A. Morality in the Philosophy of Thomas Hobbes: Cases in the Law of Nature. Cambridge: Cambridge University Press, 2009, p. 399].

47 LLOYD, S. A. Morality in the Philosophy of Thomas Hobbes: Cases in the Law of Nature. Cambridge: Cambridge University Press, 2009. p. 399.

48 RAWLS, J. A Theory of Justice. [Revised Edition]. Oxford: Oxford University Press, 1999 [1971], p. 191-192, §35. 
Em vez de Rawls destacar uma argumentação pró-legítima defesa, ainda que preventiva, ele parece usar argumentos semelhantes àqueles utilizados no estado de necessidade. A defesa legítima presume um ato injusto por uma das partes. No entanto, Rawls não foca a sua análise sobre o caráter injusto da ação do intolerante. Em vez disso, ele foca sobre a vantagem da autopreservação.

O segundo ponto de defesa reside em que, a bem da verdade, o sistema de Hobbes estatui condições mínimas de equidade. Tais condições poderiam ser verificadas mediante duas evidências. A primeira é que o escravo não tem obrigação, haja vista o contrato por ele firmado não se constituir por um ato de liberdade, ainda que seja a liberdade tal qual definida por Hobbes, a saber, como não-impedimento: "for such men, (commonly called Slaves,) have no obligation at all"49. A segunda reside naquelas cláusulas inquinadas de nulidade absoluta, cuja desobediência não se constitui injustiça ${ }^{50}$. Como bem sumariza Nagel, há condições para que uma obrigação se estabeleça,

which 'may be summarized by the statement that the individual cannot be obliged where this is logically impossible.' Among these are the conditions that the law must be knowable, that the author must be known, and that if a man is in serious danger of death, he is excused if he acts against the law to save himself ${ }^{51}$.

De mais a mais, ter-se-ia que perquirir se a dicção rawlsiana das condições de equidade faz uso de argumentos estritamente deontológicos, nos moldes kantianos, capazes de suportar uma perda total, ou se ele não operacionaliza tais condições de um modo semelhante a Hobbes, por exemplo, quando argumenta contra o princípio da utili-

49 HOBBES, T. Leviathan, or Matter, Form, and Power of a Commonwealth Ecclesiastical and Civil. [Edited by C.B. Macpherson]. London: Penguin, 1968 [1651], chap. XX.

50 "To come now to the particulars of the true Liberty of a Subject; that is to say, what are the things, which though commanded by the Soveraign, he may neverthelesse, without Injustice, refuse to do; [.. . It is manifest, that every Subject has Liberty in all those things, the right whereof cannot by Covenant be transferred. I have shewn before in the 14. Chapter, that Covenants, not to defend a mans own body, are voyd". [HOBBES, Thomas. Leviathan, or Matter, Form, and Power of a Commonwealth Ecclesiastical and Civil. [Edited by C.B. Macpherson]. London: Penguin, 1968 [1651], chap. XXI].

51 NAGEL, T. Hobbes's Concept of Obligation. Philosophical Review. p. 73. v. 68, 1959. 
dade média por este não honrar um senso de justiça que teria que estar em harmonia com os interesses não benevolentes das partes na posição original, o que ele traduz, inclusive, em regras da psicologia humana, como se pode ver nos parágrafos 27, 28, 29 e 30 de A Theory of Justice.

Senão veja-se.

Na sua crítica ao utilitarismo Rawls mobiliza vários argumentos, contudo, um dos pontos centrais do seu empreendimento reside no conceito de boa-fé. A boa-fé significa que as partes "can rely on one another to adhere to the principles adopted"52. Ora, a base de tal confiança tem que ser avaliada tendo em vista averiguar se o contratante vai honrar o contrato, mesmo que disso resulte a pior possibilidade para ele: "we must be able to honor it even should the worst possibilities prove to be the case ${ }^{\prime \prime 53}$. Se da avaliação dessa possibilidade o contratante não puder intencionar cumprir o contrato, ele não agiu de boa-fé ao contratar: "Otherwise we have not acted in good faith" 54 . Pois bem, a capacidade que as partes têm para a justiça, o senso de justiça, implica levar em conta a psicologia moral e os motivos humanos ${ }^{55}$ para se poder avaliar o quão pesado o compromisso é em relação à possibilidade motivacional para o cumprimento do mesmo. Ora, é a partir do peso do compromisso que se pode avaliar se este foi assumido de boa-fé ou de má-fé.

Por isso, desempenha papel fundamental no argumento de Rawls determinações que, tradicionalmente, são consideradas como referidas ao conceito de natureza humana, pois é a psicologia humana que se deve ter em conta para avaliar o quão pesado é cumprir o compromisso assumido. Como bem anota Rawls, é pressuposta uma determinada concepção de pessoa ${ }^{56}$.A psicologia ou o conceito de natureza humana pode ser caracterizado de várias maneiras. Rawls destaca duas dessas caracterizações. Segundo uma delas, o homem poderia ser apresentado como um ser egoísta. Tradicionalmente, se atribui essa perspectiva a Hobbes. Rawls não toma essa perspectiva. Para ele,

52 RAWLS, J. A Theory of Justice. [Revised Edition]. Oxford: Oxford University Press, 1999 [1971]. p. 153.

53 RAWLS, J. A Theory of Justice. [Revised Edition]. Oxford: Oxford University Press, 1999 [1971]. p. 153.

54 RAWLS, J. A Theory of Justice. [Revised Edition]. Oxford: Oxford University Press, 1999 [1971]. p. 153.

55 RAWLS, J. A Theory of Justice. [Revised Edition]. Oxford: Oxford University Press, 1999 [1971]. p. 154.

56 RAWLS, J. A Theory of Justice. [Revised Edition]. Oxford: Oxford University Press, 1999 [1971]. p. 152.

Rev. Filos., Aurora, Curitiba, v. 29, n. 47, p. 667-700, maio/ago. 2017 
o homem é caracterizado como "mutually disinterested" 57 . Ou seja, por um lado, ele não é um egoísta no sentido que só pensa em si, mas, por outro lado, ele não tem um interesse pelo bem do outro. Ele tem um interesse pelo seu bem. Dessas considerações, decorre, para Rawls, a lei psicológica da busca do próprio bem: "the psychological law that persons tend to love, cherish, and support whatever affirms their own good"58. Essa lei é importante para uma teoria da decisão em condições de incerteza que considera as partes como avessas ao risco. Nesse particular, Rawls pressupõe a aversão ao risco como sendo o caso normal ${ }^{59}$.

Desse modo, quando ocorre a coincidência entre o bem próprio de cada um com os princípios de justiça, pode-se pensar em um senso de justiça que não é vão, pois desperta a motivação ou a inclinação para tal: "Since everyone's good is affirmed, all acquire inclinations to uphold the scheme"60. É com base nessa tese de psicologia moral ou de natureza humana que Rawls criticará o utilitarismo como faltoso em relação à boa-fé.

Nessa perspectiva, o primeiro ponto a destacar é que na posição original o utilitarismo que as partes escolheriam seria aquele da utilidade média e não aquele da soma total de utilidade, ou seja, tratar-se-ia de "to maximize not the total but the average utility (per capita)" 61 . Tal escolha dar-se-ia, justamente, porque com o utilitarismo da utilidade média ficaria assegurada uma quantidade de felicidade igual para todos, independentemente da soma total de utilidade. Ou seja, tal opção honraria a racionalidade das partes interessadas no seu próprio bem e honraria a aversão ao risco das mesmas, sob condições de incerteza. Sabidamente, a tese básica de Rawls contra o utilitarismo, incluso o utilitarismo que defende a utilidade media, é que este pode exigir que alguns sacrifiquem o seu bem pessoal em nome do bem coletivo: "Allegiance to the social system may demand that some, particularly the less favored, should forgo advantages for the sake of the greater good of the

\footnotetext{
57 RAWLS, J. A Theory of Justice. [Revised Edition]. Oxford: Oxford University Press, 1999 [1971]. p. 131.

58 RAWLS, J. A Theory of Justice. [Revised Edition]. Oxford: Oxford University Press, 1999 [1971]. p. 155.

59 RAWLS, J. A Theory of Justice. [Revised Edition]. Oxford: Oxford University Press, 1999 [1971]. p. 149.

60 RAWLS, J. A Theory of Justice. [Revised Edition]. Oxford: Oxford University Press, 1999 [1971]. p. 155.

61 RAWLS, J. A Theory of Justice. [Revised Edition]. Oxford: Oxford University Press, 1999 [1971]. p. 140.
} 
whole" ${ }^{\prime 2}$. Por exemplo, poderia ser o caso que o favorecimento de uma certa concepção de bem poderia gerar um maior grau de utilidade média ${ }^{63}$. Pense-se, por exemplo, em uma concepção de bem com base na proibição da pornografia ou com base em uma religião civil, como pensada por Rousseau. Melhor dito, as expectations nas quais a utilidade se baseia não seriam consideradas igualmente, mesmo no caso da utilidade média, pois ela não teria preocupação com a qualidade da utilidade. Portanto, o utilitarismo não teria um dispositivo de proteção da individualidade e da particularidade da pessoa que pode escolher fins e valorá-los de forma absoluta, ao menos em certos domínios.

O diferencial da teoria da justiça proposta por Rawls é que ela funciona justamente como um dispositivo de proteção contra os piores resultados, pois garante, ao menos em circunstâncias normais (vale observar que para ele a normalidade não pode ser o caso excepcional, mas aquilo que ocorre pelo menos durante a maior parte do tempo), que os direitos fundamentais não possam ser violados, bem como que as diferenças de riqueza tenham que beneficiar os menos favorecidos: "the two principles of justice have a definite advantage. Not only do the parties protect their basic rights but they insure themselves against the worst eventualities" 64 . Por isso, considerada a natureza humana como definida acima, o contrato poderia ser assinado de boa-fé, pois o risco do pior resultado seria evitado. Como mencionado, a boa-fé pede a disposição de cumprir o contrato mesmo que ocorra o pior resultado para o contratante. Ora, ele sustenta que este não seria o caso do utilitarismo, pois, neste, as partes teriam que poder concordar com uma perda de liberdade para que uma maior quantidade de bem fosse desfrutada pelos outros: "acquiesce in a loss of freedom over the course of their life for the sake of a greater good enjoyed by others" 65 . Ou seja, ele exige que o indivíduo dê uma alta consideração ao bem dos outros: "requires some who are less fortunate to accept even lower life prospects for the sake of others" 66 .

${ }_{62}$ RAWLS, J. A Theory of Justice. [Revised Edition]. Oxford: Oxford University Press, 1999 [1971]. p. 155.
63 RAWLS, J. A Theory of Justice. [Revised Edition]. Oxford: Oxford University Press, 1999 [1971]. p. 152.
64 RAWLS, J. A Theory of Justice. [Revised Edition]. Oxford: Oxford University Press, 1999 [1971]. p. 154.
65 RAWLS, J. A Theory of Justice. [Revised Edition]. Oxford: Oxford University Press. 1999 [1971]. p. 154.
66 RAWLS, J. A Theory of Justice. [Revised Edition]. Oxford: Oxford University Press. 1999 [1971]. p. 157. 
Tendo em vista essas considerações, Rawls conclui que tais contratos não poderiam ser feitos de boa-fé porque suplantariam a capacidade da natureza humana para a fidelidade aos mesmos: "Compacts of this sort exceed the capacity of human nature" ${ }^{67}$. Deveras, segundo a lei psicológica acima estatuída, o senso de justiça de cada um implica que os princípios de justiça honrem o bem próprio do contratante, sem prejuízo de honrarem, também, o bem dos outros, já que não se trata de um jogo de soma zero. Ora, não seria este o caso do utilitarismo, já que exigiria um sacrifício maior de alguns para o maior bem dos outros.

Assim considerado, o utilitarismo exigiria um sacrifício que dificilmente seria aceitável, pois ele ordenaria um sacrifício demasiado: "accept the greater advantages of others as a sufficient reason for lower expectations over the whole course of our life" 68 . Dito claramente, a estabilidade dependeria de as pessoas serem altruístas. As pessoas teriam que aceitar menos para si para que outros se beneficiassem mais: "to accept still lower prospects of life for the sake of others" ${ }^{69}$. Seria isso que explicaria por que os utilitaristas em geral deram tanta importância à simpatia e à benevolência, pois, sem estas, a sua concepção de justiça seria socialmente instável: "Their conception of justice is threatened with instability unless sympathy and benevolence can be widely and intensely cultivated"70.

A conclusão de Rawls é que o utilitarismo é uma concepção de justiça que demanda um indivíduo que não corresponde àquilo que podemos julgar como realidade. Por isso ele chama os princípios de justiça por ele defendidos uma "more realistic idea"71. Em suma: "while the average principle of utility is the ethic of a single rational individual (with no aversion to risk) who tries to maximize his own prospects, the classical doctrine is the ethic of perfect altruists"72. Ademais, ao contrário do utilitarismo, a sua teoria da justiça não maltrataria o autorrespeito, o qual seria indispensável para a realização da concepção de bem de cada um.

${ }_{67}$ RAWLS, J. A Theory of Justice. [Revised Edition]. Oxford: Oxford University Press. 1999 [1971]. p. 154.

${ }_{68}$ RAWLS, J. A Theory of Justice. [Revised Edition]. Oxford: Oxford University Press. 1999 [1971]. p. 155.

69 RAWLS, J. A Theory of Justice. [Revised Edition]. Oxford: Oxford University Press. 1999 [1971]. p. 155.

70 RAWLS, J. A Theory of Justice. [Revised Edition]. Oxford: Oxford University Press, 1999 [1971]. p. 155.

71 RAWLS, J. A Theory of Justice. [Revised Edition]. Oxford: Oxford University Press, 1999 [1971]. p. 155.

72 RAWLS, J. A Theory of Justice. [Revised Edition]. Oxford: Oxford University Press, 1999 [1971]. p. 164-165.

Rev. Filos., Aurora, Curitiba, v. 29, n. 47, p. 667-700, maio/ago. 2017 
Essa razão deve ser acrescida àquelas que contribuem para a estabilidade. Destarte, o efeito da falta de autorrespeito é o autodesprezo. $\mathrm{O}$ autodesprezo cria instabilidade porque ele produziria os mesmos efeitos da inveja, a qual leva o indivíduo a ter ações que prejudicam os outros. Rawls é franciscano ao descrever a racionalidade das partes. Ele diz pouco sobre isso. Ele afirma, sumariamente, que ser racional é poder ter uma concepção de bem. Além disso, Rawls, explicitamente, sustenta ser irracional alguém se prejudicar para com isso prejudicar os outros: "The special assumption I make is that a rational individual does not suffer from envy. He is not ready to accept a loss for himself if only others have less as well"73. Ora, como dito, o autodesprezo teria o mesmo efeito da inveja: "Self-contempt leads to contempt of others and threatens their good as much as envy does"74. Desse modo, o utilitarismo, ao exigir o sacrifício de uns para o bem dos outros poderia levar aquele que se sacrifica a atribuir um valor menor para si do que para os outros, o que seria um caso de autodesprezo que conduziria aos mesmos efeitos da inveja, tornando a sociedade instável.

Por fim, Rawls não inquina de nulidade os termos de um contrato, cujo objeto sejam princípios utilitaristas de justiça. Contudo, ao dizer que tal contrato é instável, ele está afirmando que as partes, em razão de sua psicologia ou de sua natureza, não iriam honrá-lo. Dito de outro modo, alguém que olhasse para si mesmo com cuidado não agiria de boa-fé se assinasse um contrato com o risco mencionado, pois ele não estaria levando a sério a possibilidade do pior resultado para si e as consequências que isso implicaria, por isso, ocorrendo o pior resultado para si, ele teria a tentação de descumprir o contrato.

Ora, há duas posições bem claras em relação às quais a teoria de Rawls pode ser comparada. A de Kant, a qual sustenta a prioridade do justo sobre o bem, mesmo no caso extremo, e a de Hobbes, segundo a qual a lei natural deve ser obedecida em quase todos os casos, mas não, por exemplo, no estado de necessidade. Ou seja, para Hobbes, o caso extremo solapa qualquer fundamento de regramento, pois é um jogo

73 RAWLS, J. A Theory of Justice. [Revised Edition]. Oxford: Oxford University Press, 1999 [1971]. p. 124.

74 RAWLS, J. A Theory of Justice. [Revised Edition]. Oxford: Oxford University Press, 1999 [1971]. p. 156. 
de soma-zero. Desse modo, se mostra do modo mais visceral possível a natureza dos cálculos da razão, "For REASON, in this sense, is nothing but Reckoning"75. A implicação normativa dessa tese é que a razão não indica o que é o bem em si, mas apenas o que é bom em relação a algo que é posto como fim ${ }^{76}$.

\section{A crítica de Habermas a Rawls}

Segundo Cohen, a posição original é uma máquina produtora de justiça $^{77}$. A posição original não pede que o sujeito contratante saia da própria perspectiva. Isso ocorre porque o mecanismo que a engendra deve ser capaz de forçar a mudança do papel e do significado dos interesses individuais. Deveras, para Habermas, a posição original é uma estrutura que deveria determinar a mudança do papel e do significado dos interesses individuais ${ }^{78}$, porém, ela não consegue tal desiderato, visto que isso só se tornaria possível pela assunção de uma perspectiva intersubjetiva. No caso de Hobbes, seria a junção do interesse na autoconservação com a incerteza ${ }^{79}$ no estado de guerra que determinaria tal mudança no sentido dos interesses. Nesse diapasão, o argumento que Hobbes movimento contra o louco visaria mostrar como o interesse do contratante se coadunaria com o cumprimento do contrato, mesmo que o outro já tivesse previamente cumprido a sua parte. De fato, o que Hobbes alega contra o louco é justamente que o seu cálculo

75 HOBBES, Thomas. Leviathan, or Matter, Form, and Power of a Commonwealth Ecclesiastical and Civil. [Edited by C.B. Macpherson]. London: Penguin, 1968 [1651], chap. V.

76 "Whereas for other natural-law theorists recta ratio prescribes what is good or evil in itself, for Hobbes instead reason indicates what is good or bad in relation to a given end. Since the laws of nature are laws of reason they indicate what is good and bad in relation to a given end. Hence all the recommendations of the laws of nature listed above are valid not in absolute terms, but in relation to the attainment of a particular end. Hobbes uses the study of human nature to establish the endself-preservation and peace" [SLOMP, Gabriella. Kant against Hobbes: Reasoning and Rhetoric. Journal of Moral Philosophy. v. 4, n. 2, 2007, p. 215].

77 COHEN, G. A. Rescuing Justice and Equality. Cambridge: Harvard University Press, 2008, p. 5.

78 HABERMAS, Jürgen. The Inclusion of the Other: Studies in Political Theory. [Transl. Ciaran Cronin: Die Einbeziehung desanderen Studien zur politischen Theorie]. Cambridge: MIT Press, 1998 [1996], p. 81.

79 RAWLS, John. Lectures on the History of Political Philosophy. Cambridge, MA: Harvard University Press, 2007, p. 69. 
da vantagem que adviria de descumprir o contrato só aconteceria por acaso, logo, não seria racional descumpri-lo. Mutatis mutandis, no caso de Rawls, os interesses consistem em assegurar bens primários e a incerteza é modelada pelas condições de ignorância da posição original.

De acordo com o juízo de Habermas, as limitações do design da posição original são "morally substantive situational constraints" 80 , os quais permitem que as partes não precisem assumir o ponto de vista moral, pois tais limitações fazem com que o seu próprio interesse reflita, também, o ponto de vista daquilo que é bom para todos, porque, em sendo assim, seria bom igualmente para elas individualmente: "they find themselves constrained already by their self-interest to reflect on what is equally good for all"81. Essa seria justamente a tentativa de Rawls de modelar a posição original nos termos de uma teoria da decisão racional: "This construction of an original position that frames the freedom of choice of rational actors in a reasonable fashion is explained by Rawls's initial intention of representing the theory of justice as part of the general theory of choice" 82 .

Um dos problemas que Habermas detecta está justamente nas condições que modelam a posição original e que lhe dão razoabilidade, tornando-a equitativa [fair], pois haveria uma espécie de prioridade dessas condições de razoabilidade sobre a decisão racional que viria a resultar do seu funcionamento na posição original. Habermas de fato cita um texto de Rawls no qual ele próprio reconhece isso, qual seja,

The Reasonable, then, is prior to the Rational, and this gives the priority of right. Thus, it was an error in Theory (and a very misleading one) to describe a theory of justice as part of the theory of rational choice [...] There is no thought of trying to derive the content of justice within a framework that uses an idea of

${ }^{80}$ HABERMAS, J. The Inclusion of the Other: Studies in Political Theory. [Transl. Ciaran Cronin: Die Einbeziehung desanderen Studien zur politischen Theorie]. Cambridge: MIT Press, 1998 [1996]. p. 51.

${ }^{81}$ HABERMAS, J. The Inclusion of the Other: Studies in Political Theory. [Transl. Ciaran Cronin: Die Einbeziehung desanderen Studien zur politischen Theorie]. Cambridge: MIT Press, 1998 [1996]. p. 52.

82 HABERMAS, J. The Inclusion of the Other: Studies in Political Theory. [Transl. Ciaran Cronin: Die Einbeziehung desanderen Studien zur politischen Theorie]. Cambridge: MIT Press, 1998 [1996]. p. 52. 
the rational as the sole normative idea. That thought is incompatible with any kind of Kantian view ${ }^{83}$.

Sabidamente, ele repete essa mesma crítica em Political Liberalism ${ }^{84}$. Desse modo, seria o próprio Rawls a reconhecer uma preponderância de condições básicas de caráter normativo prévias à posição original, de tal forma que, bem compreendida, a justiça como equidade seria, sim, uma concepção política de justiça, mas de caráter moral: "a political conception of justice, which is, of course, a moral conception ${ }^{85}$ ".

Resta, agora, pensar nas consequências de uma tal afirmação para o seu construtivismo. Ora, se a teoria pressupõe uma razoabilidade prévia ao que resulta da posição original, qual o estatuto dessa razoabilidade. Na interpretação de Habermas elas seriam determinações substantivas em vez de processuais ${ }^{86}$ :

The decisive issue in the justification of the two highest principles of justice is less the deliberations in the original position than the intuitions and basic concepts that guide the design of the original position itself. Rawls introduces normative contents into the very procedure of justification, above all those ideas he associates with the concept of the moral person: the sense of fairness and the capacity for one's own conception of the good ${ }^{87}$.

${ }^{83}$ RAWLS, J. Justice as Fairness: Political not Metaphysical. Philosophy and Public Affairs, v. 14, n. 3, 1985, p. 237, nota 20. Habermas avalia essa citação como uma prova de que em $A$ Theory of Justice Rawls teria justamente tentado unir os empreendimentos de Kant e Hobbes e como uma prova de que ele considerou isso errado [HABERMAS, J. Justification and Application: Remarks on Discourse Ethics. [Transl. Ciaran Cronin: Erläuterungen zur Diskursethik]. Cambridge: The MIT Press, s/d [1991], p. 28, com referência à nota 11.

84 RAWLS, J. Political Liberalism. New York: Columbia University Press, 1996 [1993], p. 53, nota 7.

85 RAWLS, J. Justice as Fairness: Political not Metaphysical. Philosophy and Public Affairs. v. 14, n. 3, 1985, p. 237, nota 20.

86 "I believe that Rawls could avoid the difficulties associated with the design of an original position if he operationalized the moral point of view in a different way, namely, if he kept the procedural conception of practical reason free of substantive connotations by developing it in a strictly procedural manner". [HABERMAS, J. The Inclusion of the Other: Studies in Political Theory. [Transl. Ciaran Cronin: Die Einbeziehung desanderen Studien zur politischen Theorie]. Cambridge: MIT Press, 1998 [1996], p. 57].

${ }^{87}$ HABERMAS, J. The Inclusion of the Other: Studies in Political Theory. [Transl. Ciaran Cronin: Die Einbeziehung desanderen Studien zur politischen Theorie]. Cambridge: MIT Press, 1998 [1996]. p. 59. 
A conclusão que se segue, portanto, é que o conceito de pessoa não é construído, mas pressuposto pela posição original: "His concept of the person as well oversteps the boundaries of political philosophy" 88 .

O construtivismo tem estreita conexão com o kantismo. Ora, duas interpretações de Kant podem ser concebidas a esse respeito, uma delas de caráter mais intuicionista e outra de caráter mais construtivista.

O construtivismo sustenta que a substância moral não se funda em uma ordem independente de valores, mas se alicerça em procedimentos: "they are the product of an appropriately designed decision procedure" 89 . Ou seja, "that substance is best understood as constructed by free and equal people under fair conditions" $"$.

A outra interpretação possível sustenta que Kant seria um intuicionista racional ou mesmo um realista moral disfarçado ${ }^{91}$. O comentador em apreço, Kaufman, cita um texto de O'Neil, segundo o qual: "Some have thought that Kant, despite his disavowals, peddles one more form of rational intuitionism and is a covert moral realist; others, that he offers only a minimal formalism" ${ }^{\prime 2}$. Sabidamente, a interpretação de O'Neil sustenta que a teoria kantiana, em razão de seu antirrealismo, "is more radically constructive than the one that Rawls proposes" ${ }^{\prime 93}$.

Tudo isso iria muito bem se Rawls não fosse justamente um dos responsáveis pela formulação e disseminação, no mundo anglo-americano, da interpretação construtivista de Kant, em oposição a um modelo continental justamente mais intuicionista:

${ }^{88}$ HABERMAS, J. The Inclusion of the Other: Studies in Political Theory. [Transl. Ciaran Cronin: Die Einbeziehung desanderen Studien zur politischen Theorie]. Cambridge: MIT Press, 1998 [1996]. p. 73.

89 KAUFMAN, A. Rawls and Kantian Constructivism. Kantian Review, v. 17, Issue 02, 2012, p. 227.

90 KAUFMAN, A. Rawls and Kantian Constructivism. Kantian Review, v. 17, Issue 02, 2012, p. 228.

91 KAUFMAN, Alexander. Rawls and Kantian Constructivism. Kantian Review, v. 17, Issue 02, 2012, p. 228.

92 O'NEILL, Onora. Constructivism in Rawls and Kant. In: FREEMAN, SAMUEL [Ed.]. The Cambridge Companion to Rawls. Cambridge: Cambridge University Press, 2003, p. 354.

93 O'NEILL, Onora. Constructivism in Rawls and Kant. In: FREEMAN, SAMUEL [Ed.]. The Cambridge Companion to Rawls. Cambridge: Cambridge University Press, 2003, p. 354. Ver também FORMOSA, Paul. Is Kant a Moral Constructivist or a Moral Realist? European Journal of Philosophy. 2011, p. 1-27. 
This constructivist interpretation of Kant's moral thought has had a decisive influence on Kant scholarship in the Anglo-American tradition. Although many scholars in the continental tradition continue to view Kant as a rational intuitionist, [...] Kant is firmly established among Anglo-American commentators as an anti-realist and even a formalist moral thinker ${ }^{94}$.

Desse modo, com suas afirmações registradas acima, Rawls parece ter feito uma virada intuicionista. Deveras, o intuicionismo não é ausente de sua teoria. Há quem considere o capítulo II de A Theory of Justice como sendo intuicionista e o cap. III como sendo construtivista: "In chapter 2, Rawls develops an intuitive argument for the principles that makes no use of the idea of the original position and argues directly from substantive considered judgements of justice. [...] the argument developed in chapter 2 is explicitly not a constructivist argument ${ }^{95 \prime \prime}$. Ou seja, haveria como que uma mistura de elementos intuiciontas e construtivistas: "The philosopher arrives at the basic concept of the moral person and the adjunct concepts of the politically autonomous citizen, of fair cooperation, of the well-ordered society, and so forth, via a rational reconstruction of proven intuitions, that is, intuitions actually found in the practices and traditions of a democratic society" ${ }^{\prime \prime}$. É o próprio Rawls quem afirma que o conceito de pessoa é intuitivo: "Now the conception of persons as having the two moral powers, and therefore as free and equal, is also a basic intuitive idea assumed to be implicit in the public culture of a democratic society" ${ }^{\prime 97}$.

Nesse diapasão, Dworkin, baseado na afirmação de Rawls de que a posição original é puramente hipotética ${ }^{98}$, sugere ser ela um ponto intermediário de uma teoria mais profunda [deeper theory ${ }^{99}$, cujos outros pontos seriam o equilíbrio reflexivo e o contrato social. O elemento

94 KAUFMAN, Alexander. Rawls and Kantian Constructivism. Kantian Review. v. 17, Issue 02, 2012 , p. 228.

95 KAUFMAN, Alexander. Rawls and Kantian Constructivism. Kantian Review. v. 17, Issue 02, 2012, p. 240.

${ }_{96}$ HABERMAS, J. The Inclusion of the Other: Studies in Political Theory. [Transl. Ciaran Cronin: Die Einbeziehung desanderen Studien zur politischen Theorie]. Cambridge: MIT Press, 1998 [1996], p. 60. "Reflective equilibrium is achieved at the moment when the philosopher has attained the assurance that those involved can $n$ o longer reject with good reasons intuitions reconstructed and clarified in this manner" [id. Ib.].

97 RAWLS, J. Justice as Fairness: Political not Metaphysical. Philosophy and Public Affairs. v. 14, n. 3, p. 234, 1985.

98 RAWLS, J. A Theory of Justice. [Revised Edition]. Oxford: Oxford University Press, 1999 [1971], p. 19, §5.

99 DWORKIN, R. Taking Rights Seriously. London: Duckworth, 1977. p. 158. 
profundo da teoria seria "[...] a right to equal concern and respect"100. De se esclarecer que o direito ao igual respeito e consideração encontram a sua base na dignidade humana ${ }^{101}$ e que o direito fundamental do qual se trata, em última análise, não é a liberdade, mas a igualdade ${ }^{102}$. Ora, essa interpretação sugere uma proximidade com aquela de Habermas, segundo a qual operariam na teoria de Rawls determinações mais profundas do que o construtivismo. Determinações de caráter substantivo. A tese de Dworkin aponta para uma convicção de Habermas no sentido de que a teoria de Rawls teria avançado em direção a fundamentos mais profundos do que os aparentemente declinados, mormente em

${ }^{100}$ DWORKIN, R. Taking Rights Seriously. London: Duckworth, 1977. p. 180, também p. 182. Ele baseia essa sua afirmação na seguinte referência de Rawls: "A further observation is that we can now more fully reconcile two conceptions of equality. Some writers have distinguished between equality as it is invoked in connection with the distribution of certain goods, some of which will almost certainly give higher status or prestige to those who are more favored, and equality as it applies to the respect which is owed to persons irrespective of their social position. Equality of the first kind is defined by the second principle of justice which regulates the structure of organizations and distributive shares so that social cooperation is both efficient and fair. But equality of the second kind is fundamental. It is defined by the first principle of justice and by such natural duties as that of mutual respect; it is owed to human beings as moral persons. The natural basis of equality explains its deeper significance. The priority of the first principle over the second enables us to avoid balancing these conceptions of equality in an ad hoc manner, while the argument from the standpoint of the original position shows how this precedence comes about" [RAWLS, John. A Theory of Justice. [Revised Edition]. Oxford: Oxford University Press, 1999 [1971], p. 447, §77]. Aliás, essa interpretação recusada por Rawls, por ser estrita demais. Para ele, 0 conceito central é aquele de um sistema de cooperação equitativa. A ideia de pessoas livres e iguais, bem como a de direitos e obrigações seriam, para Rawls, elementos que comporiam aquele conceito central de um sistema equitativo de cooperação social: "This is an ingenious suggestion but I have not followed it in the text. I prefer not to think of justice as fairness as a right-based view; indeed, Dworkin's classification scheme of right-based, duty-based and goal-based views is too narrow and leaves out important possibilities. [...] I think of justice as fairness as working up into idealized conceptions certain fundamental intuitive ideas such as those of the person as free and equal, of a well-ordered society and of the public role of a conception of political justice, and as connecting these fundamental intuitive ideas with the even more fundamental and comprehensive intuitive idea of society as a fair system of cooperation over time from one generation to the next. Rights, duties, and goals are but elements of such idealized conceptions. [...] In this context the original position is a device of representation that models the force, not of the natural right of equal concern and respect, but of the essential elements of these fundamental intuitive ideas as identified by the reasons for principles of justice that we accept on due reflection. As such a device, it serves first to combine and then to focus the resultant force of all these reasons in selecting the most appropriate principles of justice for a democratic society. (In doing this the force of the natural right of equal concern and respect will be covered in other ways.)" [RAWLS, J. Justice as Fairness: Political not Metaphysical. Philosophy and Public Affairs, v. 14, n. 3, 1985, p. 236-237, nota 19].

${ }^{101}$ DWORKIN, R. Justice for Hedgehogs. Cambridge: Harvard University Press, 2011, p. 14. 0 fundamento da dignidade se encontra no fato da consciência: "we might think that the fact of our consciousness itself, together with the phenomenal challenge of lives to lead, itself gives us all the dignity we need or should crave" [id. ib., p. 230].

102 DWORKIN, R. Taking Rights Seriously. London: Duckworth, 1977. p. 182. 
relação ao conceito de pessoa. Como afirmado acima, tais elementos não decorreriam do contrato, mas seriam prévios a ele, devendo os mesmos ser assumidos pelo contrato ${ }^{103}$. Seria essa suposição que fundamentaria o véu de ignorância. Quem não conhecesse a sua classe social não favoreceria nenhuma classe, da mesma forma, quem não conhecesse a sua concepção de bem não favoreceria nenhuma forma de vida ${ }^{104}$. Ora, tais escolhas não são nada mais do um modo de concretizar o princípio da igualdade.

Teria, então, Rawls sucumbido à tese de que aquelas determinações substantivas da razoabilidade que compõem o véu de ignorância só poderiam ser justificadas por intuição? Nesse caso, como fica a sua crítica ao intuicionismo no $\S 7$ de $A$ Theory of Justice de que ele seria um pluralismo de princípios, sem ordem de prioridade, fornecendo diretivas contrárias em casos particulares?

Seja como for, de acordo com Habermas, Rawls, mesmo depois de sua revisão, não nega que a posição original possa operacionalizar o ponto de vista moral, desde que pressupostas as condições do véu de ignorância: "Yet even after the revision of the initial goal that the original position was designed to achieve, he has held to the view that the meaning of the moral point of view can be operationalized in this way"105. Na verdade, parece ser mais do que isso, pois o raciocínio de Rawls ainda sugere operar a partir do racional, haja vista a razão que ele oferta para as partes escolherem os princípios de justiça ser a proteção de um escopo amplo de concepções de bem, sendo que os princípios de justiça seriam como que meios para tal finalidade. Ora, tal finalidade remete à racionalidade da pessoa, não à sua razoabilidade ${ }^{106}$. A explicação que Rawls parece ofertar a esse respeito é a seguinte: "it [the conception of

${ }^{103}$ DWORKIN, R. Taking Rights Seriously. London: Duckworth, 1977. p. 181.

104 DWORKIN, R. Taking Rights Seriously. London: Duckworth, 1977. p.181.

${ }^{105}$ HABERMAS, J. The Inclusion of the Other: Studies in Political Theory. [Transl. Ciaran Cronin: Die Einbeziehung desanderen Studien zur politischen Theorie]. Cambridge: MIT Press, 1998 [1996], p. 52.

106 "For the reasons we havejust surveyed, the parties favor principles which protect a wide range of determinate (but unknown) conceptions of the good and which best secure the political and social conditions necessary for the adequate development and the full and informed exercise of the two moral powers. On the assumption that the basic liberties and their priority secure these conditions (under reasonably favorable circumstances), the two principles of justice, with the first principle prior to the second, are the principles agreed to" [RAWLS, J. Justice as Fairness: Political not Metaphysical. Philosophy and Public Affairs. v. 14, n. 3, 1985, p. 39]. 
the person] enters through the constraints of the Reasonable imposed on the parties in the original position as well as in the revised account of primary goods" 107 . Sendo a concepção de pessoa já incorporada nas condições da posição original, o raciocínio pode, então, ser tão somente racional: "[...] there the deliberations of the parties were rational and based on the determinate good of the persons represented"108.

A primeira objeção que Habermas faz é se, mesmo com todas essas considerações sobre o conceito de pessoa, ainda assim, o ponto de vista moral poderia ser operacionalizado pela posição original? Ele quer saber se "the meaning of the moral point of view can be operationalized in this way"109. Ou seja, "Can the parties in the original position comprehend the highest-order interests of their clients solely on the basis of rational egoism?" 110 Nesse ponto, ele endereça a Rawls as mesmas críticas que endereçara a Hobbes, ${ }^{111}$ qual seja, uma insuficiência cognitiva nos dispositivos da posição original para representar o ponto de vista moral que deveria atender aos interesses de todos: "But if, despite this, the parties are to understand the meaning of the deontological principles they are seeking [...] they must be equipped with cognitive competences that extend further than the capacities sufficient for rationally choosing actors who are blind to issues of justice"112. Para se vislumbrar a dimensão do problema envolvido, há que se ter presente que um produto moral é o resultado de um argumento moral, ao passo que o interesse de um indivíduo é algo dado pelo seu desejo, logo, "the cognitive content of normative statements cannot be explained in terms of instrumental rationality"113. É essa a

${ }^{107}$ RAWLS, J. The Basic Liberties and Their Priority. The Tanner Lectures on Human Values, 1981. p. 86.

${ }^{108}$ RAWLS, J. The Basic Liberties and Their Priority. The Tanner Lectures on Human Values. , 1981. p. 86.

${ }^{109}$ HABERMAS, J. The Inclusion of the Other: Studies in Political Theory. [Transl. Ciaran Cronin: Die Einbeziehung desanderen Studien zur politischen Theorie]. Cambridge: MIT Press, 1998 [1996]. p. 52.

${ }^{110}$ HABERMAS, J. The Inclusion of the Other: Studies in Political Theory. [Transl. Ciaran Cronin: Die Einbeziehung desanderen Studien zur politischen Theorie]. Cambridge: MIT Press, 1998 [1996], ]. p. 52.

${ }^{111}$ HABERMAS, J. Faktizität und Geltung: Beiträge zur Diskurstheorie des Rechts und des demokratischen Rechtsstaats. 4. Auflage, Frankfurt am Main: Suhrkamp, 1994 [1992], cap. 3.

112 HABERMAS, Jürgen. The Inclusion of the Other: Studies in Political Theory. [Transl. Ciaran Cronin: Die Einbeziehung desanderen Studien zur politischen Theorie]. Cambridge: MIT Press, 1998 [1996]. p. 53.

113 HABERMAS, J. The Inclusion of the Other: Studies in Political Theory. [Transl. Ciaran Cronin: Die Einbeziehung desanderen Studien zur politischen Theorie]. Cambridge: MIT Press, 1998 [1996]. p. 80. 
razão pela qual Rawls teria que equipar as partes na posição original com um senso de justiça e não só com a racionalidade que calcula vantagens. Ora, o senso de justiça parece desempenhar um papel importante na determinação do caráter recíproco dos princípios de justiça. Se é assim, alega Habermas,

the design loses its point by becoming too far removed from the original model. For as soon as the parties step outside the boundaries of their rational egoism and assume even a distant likeness to moral persons, the division of labor between the rationality of choice of subjects and appropriate objective constraints is destroyed, a division through which self-interested agents are nonetheless supposed to arrive at morally sound decisions ${ }^{114}$.

A segunda objeção que ele faz é com relação ao conceito de direitos, o seja, "Can basic rights be assimilated to primary goods?"115. Aliás, o próprio Rawls endereçara uma crítica semelhante a Hobbes, como visto acima. Não é sem ironia que agora Habermas lhe dirija a mesma crítica. Deveras, Habermas não só concorda com a tese do déficit obrigacional do contratualismo, como se pode ver logo a seguir na sua citação com relação ao free-rider, como a imputa ao próprio Rawls, devido ao vínculo do conteúdo com a racionalidade estratégica da posição original. Segundo ele, os homens, tais quais concebidos por Hobbes, só podem fazer seus acordos exclusivamente sob o fundamento do que é vantajoso, haja vista não estarem equipados com a liberdade da vontade. Por isso, as suas razões permanecem atadas aos interesses e preferências contingentes: ${ }^{116}$ "The contracting parties need only consider whether it is advantageous or rational for them in light of their desires and preferences to adopt a rule of action or a system of such rules. But it is well known that this strategy misses the specific obligatory force of binding norms and valid moral

\footnotetext{
114 HABERMAS, J. The Inclusion of the Other: Studies in Political Theory. [Transl. Ciaran Cronin: Die Einbeziehung desanderen Studien zur politischen Theorie]. Cambridge: MIT Press, 1998 [1996]. p. 53-54.

115 HABERMAS, J. The Inclusion of the Other: Studies in Political Theory. [Transl. Ciaran Cronin: Die Einbeziehung desanderen Studien zur politischen Theorie]. Cambridge: MIT Press, 1998 [1996]. p. 52.

${ }^{116}$ HABERMAS, J. Justification and Application: Remarks on Discourse Ethics. [Transl. Ciaran Cronin: Erläuterungen zur Diskursethik]. Cambridge: The MIT Press, s/d [1991]. p. 27.
} 
statements, as is shown by the problem of the free-rider"117. Ora, isso parece muito próximo da crítica que o próprio Rawls fizera ao argumento do louco nas Lectures.

Nesse diapasão, Habermas opera uma distinção entre direitos e bens. Segundo Habermas, bens seriam preferências, já direitos decorreriam de normas que "impose equal and exceptionless obligations"118. Tais normas que estabelecem direitos teriam uma validade binária, ou seja, não caberia ponderação como ocorreria entre bens, de tal forma que uns poderiam ser mais importantes que outros. Essa determinação pressupõe uma distinção deontológica entre os direitos e o bem que contradiz a consideração inicial de que direitos também seriam bens primários $^{119}$, ou seja, a equiparação de direitos a bens não daria conta do conceito de direitos, por exemplo, entendidos como trunfos, como defendido por Dworkin ${ }^{120}$, ou não daria conta do conceito de inviolabilidade da pessoa defendida pelo próprio Rawls:

Thus to respect persons is to recognize that they possess an inviolability founded on justice that even the welfare of society as a whole cannot override. It is to affirm that the loss of freedom for some is not made right by a greater welfare enjoyed by others. The lexical priorities of justice represent the value of persons that Kant says is beyond all price. The theory of justice provides a rendering of these ideas $[\ldots]^{121}$.

Ora, Rawls, ao equiparar tudo a bens primários, incluso direitos, alega Habermas, faz uma espécie de nivelamento da dimensão

${ }^{117}$ HABERMAS, J. The Inclusion of the Other: Studies in Political Theory. [Transl. Ciaran Cronin: Die Einbeziehung desanderen Studien zur politischen Theorie]. Cambridge: MIT Press, 1998 [1996]. p. 80.

118 HABERMAS, J. The Inclusion of the Other: Studies in Political Theory. [Transl. Ciaran Cronin: Die Einbeziehung desanderen Studien zur politischen Theorie]. Cambridge: MIT Press, 1998 [1996]. p. 55.

${ }^{119}$ HABERMAS, J. The Inclusion of the Other: Studies in Political Theory. [Transl. Ciaran Cronin: Die Einbeziehung desanderen Studien zur politischen Theorie]. Cambridge: MIT Press, 1998 [1996]. p. 56.

${ }^{120}$ HABERMAS, J. The Inclusion of the Other: Studies in Political Theory. [Transl. Ciaran Cronin: Die Einbeziehung desanderen Studien zur politischen Theorie]. Cambridge: MIT Press, 1998 [1996]. p. 57. Sobre o conceito de direitos como trunfos, ver DWORKIN, Ronald. Taking Rights Seriously. London: Duckworth, 1977.

${ }^{121}$ RAWLS, J. A Theory of Justice. [Revised Edition]. Oxford: Oxford University Press, 1999 [1971]. p. 513, §87. 
deontológica, "leveling of the deontological dimension"122, determinando que ele tenha que compensar tal nivelamento pelo conceito de prioridade do justo sobre o bem. Rawls tem que sustentar essa prioridade para bem muscular a sua tese da inviolabilidade da pessoa. Com efeito, esse é o ponto mais sensível do empreendimento de Rawls, haja vista o caráter antiutilitarista de sua teoria. Ou seja, é difícil justificar uma tal prioridade, a partir do cálculo interessado da pessoa que contrata: "is, however, difficult to justify from the first person perspective in which we orient ourselves to our own interests or values. H. L. A. Hart has developed this point clearly in his critique of Rawls"123. Como bem vislumbrou Hart, sob o ponto de vista contractual, só podem ser negociados bens: "For rationally choosing actors bound to the first person perspective, normative issues of whatever kind can be represented solely in terms of interests or values that are satisfied by goods" 124 .

Segundo Rawls, uma das falhas apontadas por Hart foi justamente no fundamento da prioridade do justo sobre o bem: "The first gap is that the grounds upon which the parties in the original position adopt the basic liberties and agree to their priority are not sufficiently explained"125. Veja-se a argumentação de Hart a esse respeito.

Hart mostra a dificuldade de estabelecer a prioridade do justo sobre o bem com base nos interesses racionais de cada um, pois, para que tal finalidade fosse assim alcançada, o argumento de Rawls teria que poder sustentar que a proibição de alguém praticar a sua religião seria pior do que a proibição para uma pessoa pobre ganhar uma vantagem econômica pela renúncia da sua liberdade religiosa que para ela significasse pouco ou nada ${ }^{126}$. Como se trata de evitar o pior, neste caso, entre a proibição da prática religiosa e a proibição de negociar a liberdade religiosa por vantagem econômica, o pior seria a proibição da

\footnotetext{
${ }^{122}$ HABERMAS, J. The Inclusion of the Other: Studies in Political Theory. [Transl. Ciaran Cronin: Die Einbeziehung desanderen Studien zur politischen Theorie]. Cambridge: MIT Press, 1998 [1996]. p. 55.

${ }^{123}$ HABERMAS, J. The Inclusion of the Other: Studies in Political Theory. [Transl. Ciaran Cronin: Die Einbeziehung desanderen Studien zur politischen Theorie]. Cambridge: MIT Press, 1998 [1996]. p. 56.

${ }^{124}$ HABERMAS, J. The Inclusion of the Other: Studies in Political Theory. [Transl. Ciaran Cronin: Die Einbeziehung desanderen Studien zur politischen Theorie]. Cambridge: MIT Press, 1998 [1996]. p. 54.

125 RAWLS, J. The Basic Liberties and Their Priority. The Tanner Lectures on Human Values. 1981. p. 4.

${ }^{126}$ HART, H. L. A. Rawls on Liberty and its Priority. In DANIELS, Norman [ed.]. Reading Rawls: Critical Studies on Raw/s' "A Theory of Justice". Stanford: Stanford University Press, 1989 [1973]. p. 252.
}

Rev. Filos., Aurora, Curitiba, v. 29, n. 47, p. 667-700, maio/ago. 2017 
prática religiosa, mesmo para uma pessoa pobre que não se importasse em nada com a religião. Ou seja, deveria ser melhor ter liberdade religiosa do que poder trocar a liberdade religiosa por benefícios econômicos. Segundo Hart, a defesa da prioridade poderia ser feita com base em um ideal liberal que considerasse a atividade política um bem supremo que não poderia ser trocado por bens materiais ou por contentamento. Porém, ajunta ele, o argumento de Rawls não se baseia em ideais, mas em interesses. Com isso, Rawls teria que poder demonstrar que a prioridade da liberdade é uma preferência a qual toda pessoa portadora de interesses deveria ter ${ }^{127}$.

Para suprir essa falha foi necessário destacar o papel e a importância do conceito de pessoa na sua argumentação: "To fill this gap I shall introduce a certain conception of the person together with a companion conception of social cooperation" ${ }^{\prime 28}$. Sem isso, não haveria como responder a Hart. Segundo Habermas, em resposta a Hart, Rawls teve justamente que operar uma "qualification into the primary goods which secures them a relation to basic liberties as basic rights" 129 . O próprio Rawls explica como o conceito de pessoa passa a funcionar na teoria revisada:

A second serious weakness of the original edition was its account of primary goods. These were said to be things that rational persons want whatever else they want, [...] Primary goods are now characterized as what persons need in their status as free and equal citizens, and as normal and fully cooperating members of society over a complete life $e^{130}$.

Com isso, volta-se ao ponto inicial da argumentação de Habermas, qual seja, a existência velada de princípios substantivos que exorbitam do construtivismo rawlsiano, ou de seu processualismo, e tangenciam predicados intuicionistas que funcionariam como um deus ex machina para justificar as falhas que a teoria contratual apresentaria.

\footnotetext{
${ }^{127}$ HART, H. L. A. Rawls on Liberty and its Priority. In: DANIELS, Norman [ed.]. Reading Rawls: Critical Studies on Rawls' "A Theory of Justice". Stanford: Stanford University Press, 1989 [1973]. p. 252.

${ }^{128}$ RAWLS, J. The Basic Liberties and Their Priority. The Tanner Lectures on Human Values. 1981, p. 13.

12956 . HART, H. L. A. Rawls on Liberty and its Priority. In DANIELS, Norman [ed.]. Reading Rawls: Critical Studies on Raw/s' "A Theory of Justice". Stanford: Stanford University Press, 1989. p. 230-252.

${ }_{130}$ RAWLS, J. A Theory of Justice. [Revised Edition]. Oxford: Oxford University Press, 1999 [1971]. p. XIII.
} 
Por fim, Habermas contesta que o véu de ignorância possa garantir a imparcialidade: "Rawls imposes a common perspective on the parties in the original position through informational constraints and thereby neutralizes the multiplicity of particular interpretive perspectives from the outset"131. Nesse sentido, ele analisa a regra de ouro que já Hobbes sustentara ser a suma da lei natural. Ele critica o que chama de um teste de universalidade egocentricamente concebido, o qual não implicaria, de modo algum, que a máxima por ele testada poderia ser aceita por todos ${ }^{132}$, haja vista operar a partir do solipsismo da perspectiva individual. Para que ocorresse essa possibilidade de operar o ponto de vista de todos, a partir do ponto de vista do individual, a perspectiva do eu deveria necessariamente ser coerente com a de todos. Porém, para tal ocorrer, a identidade do eu e o seu respectivo projeto de vida deveriam refletir uma forma de vida universalmente válida, que teria a capacidade de fazer com que a perspectiva do eu fosse igualmente a perspectiva de todos e, portanto, fosse boa para todos e no interesse de todos ${ }^{133}$. Ora, Habermas nega que isso possa acontecer, devido ao solipsismo da consciência:

For only when the self-understanding of each individual reflects a transcendental consciousness, that is, a universally valid view of the world, would what from my point of view is equally good for all actually be in the equal interest of each individual. But this can no longer be assumed under conditions of social and ideological pluralism ${ }^{134}$.

${ }^{131}$ HABERMAS, J. The Inclusion of the Other: Studies in Political Theory. [Transl. Ciaran Cronin: Die Einbeziehung desanderen Studien zur politischen Theorie]. Cambridge: MIT Press, 1998 [1996]. p. 57.

132 HABERMAS, J. Justification and Application: Remarks on Discourse Ethics. [Transl. Ciaran Cronin: Erläuterungen zur Diskursethik]. Cambridge: The MIT Press, s/d [1991]. p. 7.

133 HABERMAS, J. Justification and Application: Remarks on Discourse Ethics. [Transl. Ciaran Cronin: Erläuterungen zur Diskursethik]. Cambridge: The MIT Press, s/d [1991]. p. 7-8.

${ }^{134}$ HABERMAS, J. The Inclusion of the Other: Studies in Political Theory. [Transl. Ciaran Cronin: Die Einbeziehung desanderen Studien zur politischen Theorie]. Cambridge: MIT Press, 1998 [1996]; p. 57. 
Por isso é que ele propôs uma reformulação do próprio imperativo categórico ${ }^{135}$ : "the role of the categorical imperative is taken over by an intersubjectively applied procedure"136. Segundo ele,

Kant's categorical imperative already goes beyond the egocentric character of the Golden Rule: 'Do not do unto others what you would not have them do unto you.' Whereas this rule calls for a universalization test from the viewpoint of a given individual, the categorical imperative requires that all those possibly affected be able to will a just maxim as a general rule. But as long as we apply this more exacting test in a monological fashion, each of us still considers privately what all could will from individually isolated perspectives. This is inadequate ${ }^{137}$.

Daí se entende a marca intersubjetiva que ele dá ao princípio de universalização defendido pela ética discursiva por ele proposta: "Dei a (U) $)^{138}$ uma versão que exclui uma aplicação monológica desse princípio; [...] Como Kant, Rawls operacionaliza de tal maneira o ponto de vista da imparcialidade que cada indivíduo possa empreender por si só a tentativa de justificar normas básicas" ${ }^{139}$.

\section{Considerações finais}

Em apertada síntese, Habermas imputa a Rawls uma crítica que este fizera a Hobbes, qual seja, aquela de um déficit obrigacional nos produtos gerados pelo procedimento contratual. De outro lado, ele imputa tanto a Rawls, quanto a Hobbes, um déficit cognitivo em relação à possibilidade do procedimento contratual dar conta do ponto de vista de todos, que é exigido pela justiça. Assim, no caso de Hobbes, os argumentos de

135 HABERMAS, J. Consciência moral e agir comunicativo. (Trad. Guido A. de Almeida: Moralbewusstsein und kommunikatives Handeln). Rio de Janeiro: Tempo Brasileiro, 1989 [1983]. p. 88.

${ }^{136}$ HABERMAS, J. The Inclusion of the Other: Studies in Political Theory. [Transl. Ciaran Cronin: Die Einbeziehung desanderen Studien zur politischen Theorie]. Cambridge: MIT Press, 1998 [1996]. p. 57.

${ }^{137}$ HABERMAS, J. The Inclusion of the Other: Studies in Political Theory. [Transl. Ciaran Cronin: Die Einbeziehung desanderen Studien zur politischen Theorie]. Cambridge: MIT Press, 1998 [1996]. p. 57.

138 Princípio de universalização.

${ }^{139}$ HABERMAS, J. Consciência moral e agir comunicativo. (Trad. Guido A. de Almeida: Moralbewusstsein und kommunikatives Handeln). Rio de Janeiro: Tempo Brasileiro, 1989 [1983]. p. 87. 
estirpe moral seriam sub-repticiamente operantes via regra de ouro, a qual Hobbes diz ser a suma das leis naturais. Desse modo, alega Habermas, sub-repticiamente, Hobbes introduziria argumentos morais em sua teoria. Do mesmo modo, Rawls, acusa ele, também contrabandearia a moral para a sua teoria contratual, via o conceito de pessoa e via as condições do véu de ignorância, as quais ele interpreta como determinações morais substantivas concernentes à razoabilidade. Dito claramente, a razoabilidade não decorre como um produto da posição original, mas a precede. Em epítome, ele moraliza Hobbes e moraliza Rawls como solução para os seus problemas concernentes ao déficit cognitivo do contratualismo.

\section{Referências}

APEL, K.-O; OLIVEIRA, M. A. de; MOREIRA, L. Com Habermas, contra Habermas: direito, discurso e democracia. São Paulo: Landy, 2004.

ARISTÓTELES. Política [edição bilíngüe]. [Trad. A. C. Amaral e C. C. Gomes]. Lisboa: Vega, 1998.

BAYERTZ, K.; GUTMANN, T. Happiness and Law. Ratio Juris, v. 25, n. 2, p. 236-246, 2012.

BAYERTZ, K.; GUTMANN, T. Happiness and Law. Ratio Juris, v. 25, n. 2, p. 236-246, 2012.

BYRD, B. S.; HRUSCHKA, J. Kant's 'Doctrine of Right': A Commentary. Cambridge: Cambridge University Press, 2010.

DARWALL, S. Normativity and Projection in Hobbes's Leviathan. The Philosophical Review, v. 109, n. 3, p. 313-347, 2000.

DARWALL, S. The British Moralists and the Internal 'Ought': 1640-1740. Cambridge: Cambridge University Press, 1995.

EGGERS, D. Hobbes and Game Theory Revisited: Zero-Sum Games in the State of Nature. The Southern Journal of Philosophy, v. 49, n. 3, p. 193-226, 2011.

GAUTHIER, D. The Logic of Leviathan. Oxford: Clarendon Press, 1969. 
GREGOR, M. J. Law of Freedom: A Study of Kant's Method of Applying the Categorical Imperative in the 'Methapysik der Sitten'. Oxford: Blackwell, 1963.

GREGOR, M. J. Translator's Note on the text of The metaphysics of Morals. In: KANT, I. Practical philosophy. [Transl. Mary Gregor]. [The Cambridge Edition of The Works of Immanuel Kant]. Cambridge: Cambridge University Press, 1996. p. 355-359.

HABERMAS, J. Faktizität und Geltung: Beiträge zur Diskurstheorie des Rechts und des demokratischen Rechtsstaats. 4. Auflage, Frankfurt am Main: Suhrkamp, 1994 [1992].

HABERMAS, J. The Inclusion of the Other: Studies in Political Theory. [Transl. Ciaran Cronin: Die Einbeziehung desanderen Studien zur politischen Theorie]. Cambridge: MIT Press, 1998 [1996].

HABERMAS, J. Reconciliation through the Public Use o Reason: Remarks on John Rawls' Political Liberalism. The Journal of Philosophy, New York, v. 92, n. 3, p. 109-31, Marc. 1995.

HAMPTON, J. Hobbes and the Social Contract Tradition. Cambridge: Cambridge University Press, 1986.

HART, H. L. A. Rawls on Liberty and its Priority. In DANIELS, Norman [ed.]. Reading Rawls: Critical Studies on Rawls' "A Theory of Justice". Stanford: Stanford University Press, 1989 [1973]. p. 230-252.

HOHFELD, W. N. Faulty Analysis in Easement and License Cases. The Yale Law Journal. V. 27, n. 1, p. 66-101, 1917.

HOHFELD, W. N. Some Fundamental Legal Conceptions as Applied in Judicial Reasoning. The Yale Law Journal, v. 23, n. 1, p. 16-59, 1913.

KAVKA, G. Right Reason and Natural Law in Hobbes's Ethics. The Monist, v. 66, p. 120-33, 1983.

KAVKA, G. The Rationality of Rule-Following: Hobbes' Dispute with the Foole. Law and Philosophy, p. 5-34, v. 14, 1995. 
MILL, J. S. Utilitarianism and On Liberty. Including Mill's 'Essay on Bentham' and selections from the writings of Jeremy Bentham and John Austin. [Ed. with an Introduction by Mary Warnock]. 2. Ed., Oxford: Blackwell, 2003.

MOEHLER, M. Why Hobbes' State of Nature is Best Modeled by an Assurance Game. Utilitas, n. 21, p. 297-326, 2009.

OAKESHOTT, M. Hobbes on Civil Association. Indianapolis: Liberty Fund, 2000. PASQUINO, P. Hobbes, religion, and rational choice: Hobbes's two Leviathans and the Fool. Pacific Philosophical Quarterly, v. 82, p. 406-419, 2001.

PÉCHARMAN, M. Le problème du principe des jugements pratiques: Kant critique d'une illusion de Hobbes. In: FOISNEAU, Luc, THOUARD, Denis [ed.]. De la violence à la politique: Kant et Hobbes. Paris: Vrin, 2005. p. 33-54.

PETTIT, P. Made with Words: Hobbes on Language, Mind, and Politics. Princeton and Oxford: Princeton University Press, 2008.

RAWLS, J. A Theory of Justice. [Revised Edition]. Oxford: Oxford University Press, 1999 [1971].

RAWLS, J. Lectures on the History of Political Philosophy. Cambridge, MA: Harvard University Press, 2007.

TAYLOR, A. E. The Ethical Doctrine of Hobbes. Philosophy, n. 13, p. 406-424, 1938.

ZOFFOLI, E. The Place of Comprehensive Doctrines in Political Liberalism: On Some Common Misgivings About the Subject and Function of the Overlapping Consensus. Res Publica, v. 18, p. 351-366, 2012.

Received: 12/03/2017

Recebido: 03/12/2017

Approved: $17 / 08 / 2017$

Aprovado: 08/17/2017 